\title{
Detection of Anti-Leptospira Antibodies in Captive Nonhuman Primates From Salvador, Brazil
}

\author{
MELISSA H. PINNA ${ }^{*}$, GABRIEL MARTINS ${ }^{2}$, ANA CARLA O. PINHEIRO ${ }^{1}$, DANIELA S. ALMEIDA ${ }^{1}$, ARIANNE P. ORIÁ ${ }^{3}$, \\ AND WALTER LILENBAUM ${ }^{2}$ \\ ${ }^{1}$ Bacteriosis Laboratory, Department of Preventive Veterinary Medicine, Universidade Federal da Bahia, Salvador/BA, Brazil \\ ${ }^{2}$ Veterinary Bacteriology Laboratory, Department of Microbiology and Parasitology, Universidade Federal Fluminense, Niteróil \\ RJ, Brazil \\ ${ }^{3}$ Department of Pathology and Clinic, Universidade Federal da Bahia, Salvador/BA, Brazil
}

Leptospirosis is a widely distributed zoonosis that affects several species of domestic and wild animals. Under captive conditions, Leptospirosis is a potential problem because the physical conditions in most zoos and research centers cannot prevent the captive animals from being exposed to rodents, raccoons, opossums, and other local wildlife that are known carriers. Yet, despite the potential risk, animals that are destined for reintroduction into the wild are not routinely tested for anti-Leptospira antibodies before their release. The purpose of this study was to determine the occurrence of anti-Leptospira antibodies in captive New World monkeys that were housed in the Wild Animals Screening Center in Salvador, Brazil. Blood samples were collected from 44 monkeys (28 Callithrix jacchus, eight Callithrix pennicilata, and eight Cebus sp.). The animals were screened for antibodies with the microscopic agglutination test. Twenty-five (56.8\%) primates were seroreactive, with Icterohaemorrhagiae being the most frequent serogroup. None of the monkeys, however, presented clinical signs of leptospirosis. Thus, seroreactivity with low titers in asymptomatic animals, as observed in this study, suggests exposure to the agent. The unexpected predominance of the serogroup Icterohaemorrhagiae further suggests that exposure to this serogroup occurred in captivity. Therefore, the dangerous possibility cannot be ignored that reintroduced monkeys will carry the leptospiral serovars into wild populations. In conclusion, primates exposed to urban serovars before their release from captivity represent a potentially significant health risk to wild populations. Am. J. Primatol. 74:8-11, 2012. (C) 2011 Wiley Periodicals, Inc.

Key words: leptospirosis; nonhuman primates; diagnosis; reintroduction

\section{INTRODUCTION}

Leptospirosis is a widely distributed zoonosis that affects several species of domestic and wild animals, and humans are the endpoint of its epidemiological chain. An infected animal, even when asymptomatic, can intermittently introduce viable leptospires into the immediate environment through its urine [Faine et al., 2000].

Wildlife species are susceptible to infection with a wide variety of serovars, for which they serve as incidental hosts. Acute leptospirosis is similar in all animals. In its most flagrant form, it is manifested by listlessness, loss of appetite, irritability, fever, ruffled fur, red eyes, and sometimes diarrhea, hemorrhage, jaundice, spontaneous abortion, chronic renal failure, and death [Faine et al., 2000].

Although frequently present in Brazilian wildlife, anti-Leptospira antibodies are not often described in captive animals [Lilenbaum et al., 2002]. The occurrence of leptospirosis under captive condi- tions, however, presents a potentially significant risk. Housing conditions in zoos and research centers often cannot fully isolate the captive animals from local wildlife (e.g., rodents, raccoons, opossums, etc.), which may gain entry into these facilities [Baulu et al., 1987; Perolat et al., 1992; Scarcelli et al., 2003; Shive et al., 1969; Szonyi et al., 2011].

Captive nonhuman primates may be exposed to [Lilenbaum et al., 2005] and carry leptospirosis [Baitchman et al., 2006; Palmer et al., 1987; Szonyi et al., 2011]. Thus, projects that return wildlife to

\footnotetext{
*Correspondence to: Melissa H. Pinna, Bacteriosis Laboratory, Universidade Federal da Bahia, Avenida Adhemar de Barros, 500-Ondina, Salvador/BA, Brazil. E-mail: melissahp@ufba.br

Received 14 February 2011; revised 15 August 2011; revision accepted 21 August 2011

DOI 10.1002/ajp.21005

Published online 3 November 2011 in Wiley Online Library (wiley onlinelibrary.com).
} 
their natural habitats should implement a strict quarantine-60 days for primates-and veterinary program for these animals before their release. A variety of screening tests are recommended by the International Union for Conservation of Nature [IUCN, 1998], but a test for anti-Leptospira antibodies is not currently one of them. Not screening for these antibodies represents a risk, because Leptospira is dangerous for humans as well as domestic animals, wildlife, and ecosystems in general [Woodford, 2001]. In an attempt to assess the extent of this risk, this study investigated the occurrence of anti-Leptospira antibodies in representatives of New World monkey species that were being held in captivity for health screening, before being returned to their natural habitats.

\section{METHODS}

The study was approved by the Research Ethics Committee of Federal University of Bahia (process no 025/09-A) and by the Environmental Department of Brazil (IBAMA-SISBIO no 20.831-1). This research adhered to the American Society of Primatologists principals for the ethical treatment of primates.

In September 2009, blood samples were collected from 44 monkeys (28 Callithrix jacchus, 8 Callithrix pennicilata, and 8 Cebus sp.) held in captivity at the Chico Mendes Wild Animal Screening Center, a facility located near the Federal University of Bahia in Salvador, Brazil. The monkeys had been brought to the Center by the Brazilian legal authorities following the arrest of poachers who had trapped the animals in the forest for the purpose of selling them on the black market. None of the monkeys had been vaccinated against leptospirosis. Before the samples were collected, the animals were anesthetized (Ketamine hydrochloride 10\%, 20-30 mg/kg IM) and then given a complete clinical examination.

After separation by centrifuge, the serum was stored in $2 \mathrm{ml}$ aliquots at $-20^{\circ} \mathrm{C}$ for subsequent testing in the Veterinary Bacteriology Laboratory at the Universidade Federal Fluminense in Rio de Janeiro, Brazil. Antibodies were screened at a dilution of 1:50 with the microscopic agglutination test (MAT) for the most frequent serogroups in this area [Lilenbaum et al., 2005]: L. interrogans serovars Australis (Ballice), Bataviae (Van Tienen), Canicola (Hond Utrecht IV), Icterohaemorrhagiae (RGA), Copenhageni (M 20), Pomona (Pomona), Pyrogenes (Salinem), and Wolffi (3705); L. borgpetersenii serovar Ballum (Mus 127); and L. kirshneri serovar Grippotyphosa (Moskva V). The serovars were grown in an Ellinghausen liquid medium, which was free of contamination or autoagglutination. For each sample with agglutinating activity at a 1:50 dilution, the antibody titer was established by preparing additional two-fold serial dilutions according to
Lilenbaum et al. [2002]. The antigen that gave the highest titer was considered to be the infective serogroup. Samples were considered to be reactive if the titer value was equal to or greater than 100 .

\section{RESULTS}

At the time of sampling, none of the 44 monkeys studied presented clinical signs of leptospirosis. Twenty-five (56.8\%) were seroreactive (titers $\geq 100$ ). Of this seroreactive group, the serogroup Icterohaemorrhagiae was found most frequently ( 21 monkeys or $84 \%$ ), followed by the serogroup Canicola (4 monkeys or $16 \%$ ).

Seroreactivity was most commonly observed in Cebus sp. (62.5\%), followed by C. jacchus (57.1\%) and C. pennicilata (50\%). Titers ranged from 100 to 200 , indicating exposure to the agent. No animal presented titer values greater than 200 (Table I).

\section{DISCUSSION}

Seroreactivity was very high in the monkeys investigated in this study (56.8\%), higher than that reported in tamarins from Rio de Janeiro, Brazil: $35.6 \%$ [Lilenbaum et al., 2005], squirrel monkeys from French Guiana: 26\% [Perolat et al., 1992], or vervet monkeys in Barbados: 29.9\% [Baulu et al., 1987]. Despite this high seroreactivity, however, none of the monkeys in this study presented clinical signs related to leptospirosis.

The MAT requires significant expertise to perform, and interlaboratory variation in results is high. Despite these limitations, the MAT has epidemiological value, and it is often used to give an indication of the presumptive serovar or serogroup of leptospires involved in an infection [Levett, 2003; Smythe et al., 2009; Sykes et al., 2011].

A nonhuman primate acquiring acute leptospirosis with high titers while living in the wild is uncommon [Minnette, 1966]. As found by others [Szonyi et al., 2011], however, this investigation reveals that monkeys can nevertheless carry the infection at low titers and not present specic signs or symptoms. Such cases suggest that the animals have been exposed to the agent. Moreover, following exposure, some monkeys may shed leptospires through intermittent leptospiruria (i.e., passing

TABLE I. Anti-Leptospira Antibodies in 44 Captive Primates From Salvador, Brazil

\begin{tabular}{lrrrrrrr}
\hline & \multicolumn{6}{c}{ Anti-Leptospira titers } \\
\cline { 2 - 7 } Species & $<100$ & 100 & 200 & 400 & $\geq 800$ & Total \\
\hline Callithrix jaccus & 12 & 11 & 5 & - & - & 28 \\
Callithrix pennicilata & 4 & 4 & - & - & - & 8 \\
Cebus sp. & 3 & 3 & 2 & - & - & 8 \\
Total & 19 & 18 & 7 & - & - & 44 \\
\hline
\end{tabular}


leptospires in urine) [Baitchman et al., 2006; Szonyi et al., 2011].

Wildlife populations are frequently seroreactive to the serovars that are prevalent in their environmental surroundings [Lins \& Lopes, 1984]. For Brazilian monkeys living in the wild, the most frequent serovars are Javanica, Ballum, Tarassovi, and Grippotyphosa [Correa et al., 1965]. Thus, this study's finding that $84 \%$ of the seroreactive monkeys have been exposed to the serogroup Icterohaemorrhagiae is surprising. This serogroup is reported in urban areas worldwide, including Salvador, the city in which the monkeys in this study were housed [Ko et al., 1999]. Although in captivity, animals can be exposed to urban serovars. Compared with their counterparts in the wild, captive monkeys spend more time on the ground, increasing their chances of contact with ground-dwelling urban rodents that are known carriers of leptospirosis, especially of serovars in the serogroup Icterohaemorrhagiae [Lilenbaum et al., 2002].

Considering the above, we suggest that the monkeys were not exposed to Icterohaemorrhagiae in the wild, but in captivity. A similar situation has been recently reported in Colombia [Szonyi et al., 2011], where capuchin monkeys (Cebus sp.) in a rehabilitation center were infected with the serovar Copenhageni (a member of serogroup Icterohaemorrhagiae), triggering an outbreak.

Direct transmission of Leptospira among monkeys has already been reported [Baulu et al., 1987]. Although not demonstrated in this study, Leptospira-exposed monkeys are known to become carriers [Baitchman et al., 2006; Szonyi et al., 2011]. Nevertheless, studies of the actual risk or frequency of primates serving as permanent or temporary reservoirs for leptospires are lacking. Additionally, once they have recovered from the illness, infected monkeys act as renal carriers, at least for a short time period [Baitchman et al., 2006; Szonyi et al., 2011]. Therefore, the possibility that infected monkeys can carry leptospiral serovars from captivity into the wild cannot be ignored. Although not yet confirmed, these reintroduced animals pose a potential health risk to wild populations [Daszak et al., 2000], particularly in tropical areas where the infection is common.

We recommend that a program be adopted that (1) isolates infected animals and (2) emphasizes the implementation of sanitation initiatives and hygienic conditions (e.g., routinely disinfecting shelters, minimizing exposure to stagnant water, rodent control) [Troedsson, 1997].

In conclusion, primates may be exposed to urban leptospiral serovars (e.g., Icterohaemorrhagiae) and represent a significant health risk to wild populations. To minimize this risk, we recommend that captive monkeys living naturally in those regions where the disease is endemic be tested for
anti-Leptospira antibodies before being released back into the wild.

\section{ACKNOWLEDGMENTS}

This study was supported by Fundação Carlos Chagas Filho de Amparo à Pesquisa do Estado do Rio de Janeiro (FAPERJ). WL is a fellow of Conselho Nacional de Desenvolvimento Científico e Tecnológico (CNPq).

\section{REFERENCES}

Baitchman EJ, Calle PP, James SB, Linn MJ, Raphael BL. 2006. Leptospirosis in Wied's marmosets (Callithrix kuhlii). Journal of Zoo and Wildlife Medicine 37:182-185.

Baulu J, Everard COR, Everard JD. 1987. Leptospires in vervet monkeys (Cercopithecus aethiops sabaeus) on Barbados. Journal of Wildlife Diseases 23:60-66.

Correa MOA, Hyakutake S, Natale V, Galvao PAA, Aguiar HA. 1965. Estudos sobre a Leptospira wolffi em São Paulo. Revista do Instituto Adolfo Lutz 25/27:11-25.

Daszak P, Cunningham AA, Hyatt AD. 2000. Emerging infectious diseases of wildlife-threats to biodiversity and human health. Science 287:443-449.

Faine S, Adler B, Bolin C, Perolat P. 2000. Leptospira and leptospirosis. Melbourne: MediSci. $272 \mathrm{p}$.

IUCN. 1998. IUCN guidelines for re-introductions. Prepared by the IUCN/SSC re-introduction specialist group. Switzerland and Cambridge, UK: IUCN, Gland. $10 \mathrm{p}$.

Ko AI, Reis MG, Dourado CMR, Johnson WD, Riley LW. 1999. Urban epidemic of severe leptospirosis in Brazil. Salvador leptospirosis study group. The Lancet 354: 820-825.

Levett PN. 2003. Usefulness of serologic analysis as a predictor of the infecting serovar in patients with severe leptospirosis. Clinical Infectious Diseases 36:447-452.

Lilenbaum W, Monteiro RV, Ristow P, Fraguas S, Cardoso VS, Fedullo LP. 2002. Leptospirosis antibodies in mammals from Rio de Janeiro Zoo, Brazil. Research in Veterinary Science 73:319-321.

Lilenbaum W, Varges R, Moraes IA, Ferreira AM, Pissinatti A. 2005. Leptospiral antibodies in captive lion tamarins (Leontopithecus sp) in Brazil. The Veterinary Journal 169:462-464.

Lins ZC, Lopes ML. 1984. Isolation of Leptospira from wild forest animals in mazonian Brazil. Transaction of Royal Society of Tropical Medicine and Hygiene 78:124-126.

Minnette HP. 1966. Leptospirosis in primates other than man. American Journal of Tropical Medicine and Hygiene 15:190-198

Palmer MF, Waitkins SA, Fitzgeorge RB, Baskerville A. 1987. Experimental infection of monkeys with Leptospira interrogans serovar hardjo. Epidemiology and Infection 98:191-197.

Perolat P, Poingt JP, Vie JC, Jouneau C, Baranton G, Gysin J. 1992. Occurrence of severe leptospirosis in a breeding colony of squirrel monkeys. American Journal of Tropical Medicine and Hygiene 46:538-545.

Scarcelli E, Piatti RM, Fedullo JDL, Simon F, Cardoso MV, Castro V, Miyashiro S, Genovez M. 2003. Leptospira spp detection by polymerase chain reaction (PCR) in clinical samples of captive black-capped capuchin monkey (Cebus apella). Brazilian Journal of Microbiology 34:143-146.

Shive RJ, Green SS, Evans LB, Garner FM. 1969. Leptospirosis in Barbary apes (Macaca sylvana). Journal of American Veterinary Medical Association 155:1176-1178.

Smythe LD, Wuthiekanun V, Chierakul W, Suputtamongkol Y, Tiengrim S, Dohnt MF, Symonds ML, Slack AT, Apiwattanaporn A, Chueasuwanchai S, Day NP, Peacock SJ. 
2009. The microscopic agglutination test (MAT) is an unreliable predictor of infecting Leptospira serovar in Thailand. The American Journal of Tropical Medicine and Hygiene 81: 695-697.

Sykes JE, Hartmann K, Lunn KF, Moore GE, Stoddard RA, Goldstein RE. 2011. ACVIM small animal consensus statement on leptospirosis: diagnosis, epidemiology, treatment, and prevention. Journal of Veterinary Internal Medicine 25:1-13.
Szonyi B, Agudelo-Flórez P, Ramírez M, Moreno N, Ko AI 2011. An outbreak of severe leptospirosis in capuchin (Cebus) monkeys. The Veterinary Journal 188: 237-239.

Troedsson MHT. 1997. Abortion. In: Robinson NE, editor. Current therapy in equine medicine. Philadelphia: WB Saunders Company. p 534-540.

Woodford MH. 2001. Quarantine protocols and health screening protocols for wildlife prior to translocation and release in to the wild. Paris: Office International des Epizooties. 104 p. 